\title{
INVESTIGATIONS INTO THE ANTI-FERTILITY EFFECT OF INTRA-UTERINE DEVICES IN THE EWE
}

\author{
H. W. HAWK \\ Animal Husbandry Research Division, U.S. Department of Agriculture, \\ Beltsville, Maryland, U.S.A.
}

(Received 2nd May 1966)

\begin{abstract}
Summary. Ovum fertilization after natural mating was inhibited in both oviducts after the insertion of a plastic spiral into one uterine horn. Spermatozoa were found in oviducts of control ewes between 4 and $24 \mathrm{hr}$ after mating, but were almost totally absent from both oviducts of ewes with a spiral in one horn. Sperm numbers in the uterus were relatively low in 'spiral' ewes. Spirals had these effects both 2 to 4 weeks and 8 to 10 months after insertion.

Ova were fertilized in 'spiral' as well as control ewes after injection of semen into the uterus, but there were fewer accessory spermatozoa in ova from 'spiral' ewes. After injection of semen into one uterine horn, spermatozoa were found throughout reproductive tracts of 'spiral' and control ewes, but most spermatozoa in horns containing a spiral were broken into heads and tails. Similarly, when semen was injected into ligated uterine compartments, most spermatozoa recovered $5 \mathrm{hr}$ later from spiral compartments were tailless; most spermatozoa recovered from non-spiral compartments of the same ewes were intact. Spirals inhibited sperm transport following natural mating, and they also promoted spermicidal conditions in the uterine lumen.
\end{abstract}

\section{INTRODUCTION}

Fertilization of ova was inhibited in the ewe by the presence of a plastic spiral in the uterine lumen (Hawk, 1965). The fertilization failure appeared tentatively to be due to a lack of spermatozoa in the oviducts.

The results mentioned above were obtained after devices had been in the uterus for 2 to 4 weeks. This report concerns the anti-fertilization effect of such devices after 8 to 10 months in the uterus, and the results of other investigations related to this effect.

\section{MATERIALS AND METHODS}

The ewes were mostly Hampshire-Rambouillet crossbreds. They were checked for oestrus twice daily by vasectomized rams; the presence of seminal fluids in the reproductive tracts of the ewes was avoided by the use of aprons on the rams. 
Surgical procedures were conducted with ewes under sodium pentobarbital anaesthesia.

Polyethylene plastic spirals were made and inserted aseptically into the uterus by surgery as described previously (Hawk, 1965). They were inserted into most ewes between the 12th and 14th days of the oestrous cycle. The inserted spirals were 4.5 to $5 \mathrm{~cm}$ in length and varied from 5 to $7 \mathrm{~mm}$ in diameter, depending upon the size of the uterus. In ewes termed 'experimental', a spiral was placed in the lumen of one uterine horn slightly anterior to the external bifurcation. In ewes designated as controls, a spiral was inserted and removed immediately. The procedures followed in conducting individual experiments are given below.

\section{Ovum fertilization}

Ewes were mated three or four times with fertile rams when first detected in oestrus and three or four times again $\frac{1}{2}$ day later. They were killed 3 days after the first detection of oestrus, 66 to $76 \mathrm{hr}$ after the first matings, and ova were recovered by flushing the oviducts with saline solution $(0.9 \% \mathrm{NaCl})$. Ova were examined microscopically for cleavage and the presence of spermatozoa in the zona pellucida.

\section{Sperm transport}

The ewes were mated six times with at least four rams over a period of $30 \mathrm{~min}$ on the 1st day of oestrus. Ewes were killed at intervals of 4, 8, 12, 16, 20 and $24 \mathrm{hr}$ after the first mating. The abdominal cavity was opened and the pelvic bone was cut to expose the reproductive tract without excessive handling or stretching. Before the tract was removed from the ewe, it was clamped with haemostatic forceps at the tubo-uterine junctions, the base of the uterine horns and the posterior end of the cervix.

Each oviduct was flushed with $5 \mathrm{ml}$ of saline solution, and stripped between the fingers several times during the flushing. Repeat flushings failed to yield additional spermatozoa. Uterine horns, clamped at each end, were injected with about $10 \mathrm{ml}$ of saline solution, manipulated vigorously to suspend spermatozoa and other cells in solution and drained of their contents. Uterine bodies were washed over a funnel with a stream of saline solution from a syringe and needle. Cervices were opened longitudinally and shaken in a bottle of saline solution, after first washing the external cervical os. The separate parts of each tract were flushed consecutively from the oviducts to the cervix, and care was taken throughout the procedure to prevent contamination of one part of the tract with spermatozoa from another part.

Several hours after flushing, when sperm motility had subsided, washings from each part of the tract were, if necessary, concentrated by centrifugation or diluted and aliquots were placed in eosinophil counting chambers $0.2 \mathrm{~mm}$ deep. Sperm counts were made at $200 \times$ by phase microscopy after allowing at least $15 \mathrm{~min}$ for spermatozoa and other cells to settle from suspension. Two or $3 \mathrm{~mm}^{3}$ of flushings were examined from each of four to eight separate aliquots, and the total number of spermatozoa flushed from each part of the tract was calculated. 
Ovum fertilization following intra-uterine insemination

Semen was collected by artificial vagina and $0.04 \mathrm{ml}$ was injected within 10 min into each uterine horn of laparotomized ewes about $3 \mathrm{~cm}$ posterior to the tubo-uterine junction. Control and experimental ewes were inseminated in pairs about $6 \mathrm{hr}$ after the first detection of oestrus. Spirals had been inserted into the experimental ewes about 1 month previously. The ewes were killed on the 3rd day after insemination and each recovered ovum was examined for the number of blastomeres it contained and for the approximate number of spermatozoa attached to the zona pellucida.

\section{Sperm movement after intra-uterine insemination}

Semen $(0.07 \mathrm{ml})$ was injected at the level of the external bifurcation into one uterine horn of oestrous control ewes and into the uterine horn of oestrous experimental ewes opposite to the horn containing the spiral. Ewes were killed $6 \mathrm{hr}$ later. Reproductive tracts were flushed and spermatozoa were counted as described above. In instances where sperm cells were separated into heads and tails, counts were made both of intact spermatozoa and sperm heads. Spirals had been present in one horn of experimental ewes for 1 to 2 months.

\section{Sperm breakage in utero}

Each uterine horn of ewes in oestrus was ligated near the tubo-uterine junction and near the uterine body to form one compartment, or else it was ligated in three places to form two compartments, one of which contained the spiral. In no case was the spiral moved within the uterine lumen. Semen $(0.05$ to $0.07 \mathrm{ml}$ ) was injected into each compartment and the ewes were killed $5 \mathrm{hr}$ later. Counts were made both of intact spermatozoa and sperm heads flushed from each compartment.

\section{Ovum fertilization}

\section{RESULTS}

Spirals were inserted when the ewes were about 1 year of age. The ewes were kept through one anoestrous season and used experimentally during their second breeding season when they were approaching 2 years of age and the spirals had been in place for 8 to 10 months.

Eight ova were recovered from five control ewes (Table 1). Seven ova were cleaved, each one containing four to twelve blastomeres. Accessory spermatozoa in the zonae ranged in number from about six to more than fifty.

Fourteen ova were recovered from nine ewes with a spiral in one uterine horn. Thirteen were uncleaved and no spermatozoa were found in the zonae; one ovum contained four blastomeres, and one accessory spermatozoon was found in the zona pellucida. An uncleaved ovum was recovered from the opposite oviduct of the same ewe.

Of the fourteen ova from experimental ewes, nine uncleaved ova in six ewes were recovered from oviducts on the side of the spiral. Four uncleaved ova and one cleaved ovum in four ewes were recovered from oviducts contralateral to the uterine horn containing the spiral. 


\section{Sperm transport}

The effect of intra-uterine spirals on sperm transport was studied in yearling ewes with spirals in utero for 2 to 4 weeks $(0.5$ to 1 month, Table 2$)$, and again in ewes nearing 2 years of age, when spirals had been in place for 8 to 10 months.

\section{TABLE 1}

EFFEGT OF PLASTIC SPIRALS in utero FOR 8-10 MONTHS ON OVUM FERTILIZATION IN THE EWE

\begin{tabular}{l|c|c|c|c|c}
\hline \multicolumn{1}{c|}{$\begin{array}{c}\text { Ewe } \\
\text { group }\end{array}$} & $\begin{array}{c}\text { No. } \\
\text { of } \\
\text { ewes }\end{array}$ & $\begin{array}{c}\text { No. of } \\
\text { ovulation } \\
\text { points }\end{array}$ & $\begin{array}{c}\text { No. of } \\
\text { ova } \\
\text { recovered }\end{array}$ & $\begin{array}{c}\text { No. of } \\
\text { ova } \\
\text { cleaved }\end{array}$ & $\begin{array}{c}\text { No. of ova } \\
\text { with } \\
\text { accessory } \\
\text { spermatozoa }\end{array}$ \\
\hline $\begin{array}{l}\text { Control } \\
\text { Experimental }\end{array}$ & 5 & 8 & 8 & 7 & 7 \\
\hline
\end{tabular}

Within each age group, two ewes, an experimental and a control, were examined at each 4-hr interval between 4 and $24 \mathrm{hr}$ after mating. This covered the period of time when abnormalities in sperm transport would most likely be detected. In the 8 to 10 -month group, two additional ewes were examined at

\section{TABLE 2}

EFFECT OF PLASTIG SPIRALS in utero FOR TWO PERIODS OF TIME ON NUMBERS OF SPERMATOZOA FLUSHED FROM THE REPRODUCTIVE TRAGTS OF EWES

\begin{tabular}{|c|c|c|c|c|c|c|c|c|}
\hline \multirow[b]{3}{*}{ Ewe group } & \multirow[b]{3}{*}{$\begin{array}{c}\text { Spirals } \\
\text { in } \\
\text { utero } \\
\text { (months) }\end{array}$} & \multirow[b]{3}{*}{$\begin{array}{c}\text { Hours } \\
\text { post } \\
\text { breeding }\end{array}$} & \multirow[b]{3}{*}{$\begin{array}{l}\text { No. } \\
\text { of } \\
\text { ewes }\end{array}$} & \multicolumn{5}{|c|}{ Sites from which sperm were flushed } \\
\hline & & & & \multicolumn{2}{|c|}{$\begin{array}{c}\text { Individual } \\
\text { oviducts }\end{array}$} & \multicolumn{2}{|c|}{$\begin{array}{c}\text { Individual } \\
\text { uterine horns }\end{array}$} & \multirow{2}{*}{$\begin{array}{c}\text { Cervices } \\
\text { Mean No. } \\
\text { sperm. } \\
\text { (millions)* }\end{array}$} \\
\hline & & & & $\begin{array}{c}\text { No. } \\
\text { in which } \\
\text { sperm. } \\
\text { found: } \\
\text { not found }\end{array}$ & $\begin{array}{c}\text { Mean } \\
\text { No. } \\
\text { sperm. } \\
\text { where } \\
\text { found }\end{array}$ & $\begin{array}{c}\text { No. } \\
\text { in which } \\
\text { sperm. } \\
\text { found: } \\
\text { not found }\end{array}$ & $\begin{array}{c}\text { Mean } \\
\text { No. } \\
\text { sperm. } \\
\text { where } \\
\text { found }\end{array}$ & \\
\hline $\begin{array}{l}\text { Control } \\
\text { Experimental }\end{array}$ & 0.5 to 1 & $\begin{array}{l}4 \text { to } 12 \\
4 \text { to } 12\end{array}$ & $\begin{array}{l}3 \\
3\end{array}$ & $\begin{array}{l}4: 2 \dagger \\
1: 5\end{array}$ & $\begin{array}{r}1450 \\
87\end{array}$ & $\begin{array}{l}4: 2 \dagger \\
4: 2 \ddagger\end{array}$ & $\begin{array}{r}76400 \\
2870\end{array}$ & $\begin{array}{l}1 \cdot 4 \\
2 \cdot 2\end{array}$ \\
\hline $\begin{array}{l}\text { Control } \\
\text { Experimental }\end{array}$ & $0 . \overline{5}$ to 1 & $\begin{array}{l}16 \text { to } 24 \\
16 \text { to } 24\end{array}$ & $\begin{array}{l}3 \\
3\end{array}$ & $\begin{array}{l}6: 0 \\
0: 6\end{array}$ & $\begin{array}{c}13000 \\
-\end{array}$ & $\begin{array}{l}6: 0 \\
1: 5\end{array}$ & $\begin{array}{r}47300 \\
606\end{array}$ & $\begin{array}{l}3.2 \\
0.1\end{array}$ \\
\hline $\begin{array}{l}\text { Control } \\
\text { Experimental }\end{array}$ & 8 to 10 & $\begin{array}{l}4 \text { to } 12 \\
4 \text { to } 12\end{array}$ & $\begin{array}{l}3 \\
3\end{array}$ & $\begin{array}{l}4: 2 \ddagger \\
1: 5\end{array}$ & $\begin{array}{l}51 \\
17\end{array}$ & $\begin{array}{l}6: 0 \\
3: 3 \ddagger\end{array}$ & $\begin{array}{r}6140 \\
885\end{array}$ & $\begin{array}{r}11 \cdot 2 \\
0.5\end{array}$ \\
\hline $\begin{array}{l}\text { Control } \\
\text { Experimental }\end{array}$ & 8 to 10 & $\begin{array}{l}16 \text { to } 24 \\
16 \text { to } 24\end{array}$ & $\begin{array}{l}4 \\
4\end{array}$ & $\begin{array}{l:l}8 & : 0 \\
0 & : 8\end{array}$ & $\begin{array}{l}538 \\
-\end{array}$ & $\begin{array}{l}7: 1 \\
1: 7\end{array}$ & $\begin{array}{r}8340 \\
109\end{array}$ & $\begin{array}{l}1 \cdot 8 \\
0 \cdot 1\end{array}$ \\
\hline
\end{tabular}

* Spermatozoa were found in the cervix of each ewe.

† Spermatozoa were not found in the oviducts or uterine horns of one ewe.

\$ Spermatozoa were not found in one or both oviducts or uterine horns of two ewes.

$24 \mathrm{hr}$. In order to present the data in a relatively concise form, the ewes within the 2- to 4-week and 8- to 10-month classifications were grouped into those killed at 4, 8 and $12 \mathrm{hr}$ after mating and those killed at 16, 20 and $24 \mathrm{hr}$ (Table 2). 
Spermatozoa were not found in flushings of several individual oviducts and uterine horns. In such cases, more than $10 \%$ of the total volume of each oviduct flushing was actually examined microscopically, as was 0.5 to $1 \%$ of each uterine horn flushing. Therefore, any uncounted spermatozoa which may have been present in these flushings averaged less than ten for oviducts and less than 100 to 200 for uterine horns. For practical purposes, these cases were classified simply as those in which spermatozoa were not found (Table 2). The mean sperm numbers given in the table cover only those individual oviducts or uterine horns in which spermatozoa were found.

The number of spermatozoa flushed from any given part of the reproductive tract varied greatly among ewes; in order to reduce the inflating effect on the means of a few relatively high numbers, each individual sperm count was converted to its logarithm. Each mean given in the table is the anti-log of the mean $\log$.

Spermatozoa were found in flushings from twenty-two of the total of twentysix oviducts from control ewes (Table 2). In contrast, they were found only in two of the twenty-six oviducts from ewes with a spiral in one uterine horn $(P<0.01)$. One of these oviducts was on the side of the spiral, and one was contralateral to it. This effect of the spiral, presumably inhibition of sperm transport into the oviducts, occurred with equal frequency in ewes with spirals in place for 2 to 4 weeks and for 8 to 10 months.

Spermatozoa were found in twenty-three of twenty-six individual uterine horns in control ewes, and only in nine of twenty-six horns in experimental ewes $(P<0.01)$. The mean numbers of counted spermatozoa were also markedly less in experimental ewes than in controls.

In the experimental ewes, spermatozoa were found in three of thirteen individual uterine horns containing a spiral, the numbers being 1240, 16,500 and 53,300 ; most of the spermatozoa in the latter two cases were separated into heads and tails. Spermatozoa were found in six of the thirteen contralateral horns, in numbers ranging from 104 to 2430.

Of six experimental ewes killed 4 to $12 \mathrm{hr}$ after mating, spermatozoa were found in one or both uterine horns of five; of seven experimental ewes killed 16 to $24 \mathrm{hr}$ after mating, spermatozoa were found only in one horn of each of two ewes. Since the number of spermatozoa found in uterine horns of control ewes did not decrease appreciably with time, it appears that intra-uterine spirals curtailed the presence of spermatozoa in the uterus more drastically during the later time period after mating than during the earlier period.

Spermatozoa were found in uterine bodies of seven of the thirteen experimental ewes, mostly during the first $12 \mathrm{hr}$ after mating, and in uterine bodies of twelve of the thirteen control ewes. The numbers of spermatozoa washed from uterine bodies generally equalled about one-half of those flushed from a uterine horn of the same ewe.

The numbers of spermatozoa washed from cervices varied greatly among ewes, but tended to be higher in control than in experimental ewes.

In general, fewer spermatozoa were flushed from the oviducts and uterine horns of control ewes for the 8- to 10-month group than from control ewes for the 2- to 4-week group (Table 2). The reason for this difference is not known. 
The ewes in the 2- to 4-week group in this experiment are those previously mentioned briefly (Hawk, 1965).

\section{Inflammatory responses to intra-uterine devices}

Uterine endometrium from ewes killed 3 days after mating for ovum fertilization studies appeared grossly normal when the horns were opened longitudinally. Pus seldom adhered to the spirals, although a thin film of cellular debris was sometimes seen on the endometrium around the spiral.

When uterine horns were flushed for sperm recovery after natural insemination (Table 2), the flushings from 'spiral' horns always contained about $0.05 \mathrm{ml}$ of polymorphonuclear and monocytic leucocytes, equivalent to about 75 million cells. Leucocytes were not noticeably present in flushings from non-spiral horns of the same ewes.

Tissue specimens from uterine horns were routinely fixed in Bouin's solution, sectioned, stained with haematoxylin and eosin and examined microscopically.

TABLE 3

OVUM FERTILIZATION AFTER INJEGTION OF SEMEN INTO THE ANTERIOR END OF EACH UTERINE HORN

\begin{tabular}{l|c|c|c|c|c|c}
\hline \multicolumn{1}{c|}{$\begin{array}{c}\text { Ewe } \\
\text { group }\end{array}$} & $\begin{array}{c}\text { No. } \\
\text { of } \\
\text { ewes }\end{array}$ & $\begin{array}{c}\text { No. of } \\
\text { ovulation } \\
\text { points }\end{array}$ & $\begin{array}{c}\text { No. of } \\
\text { ova } \\
\text { recovered }\end{array}$ & $\begin{array}{c}\text { No. of } \\
\text { ova } \\
\text { cleaved }\end{array}$ & $\begin{array}{c}\text { Mean } \\
\text { No. of } \\
\text { blasto- } \\
\text { meres }\end{array}$ & $\begin{array}{c}\text { No. of sperm. } \\
\text { in zona } \\
\text { pellucida }\end{array}$ \\
\hline $\begin{array}{l}\text { Control } \\
\text { Experimental }\end{array}$ & 5 & $\mathbf{8}$ & 7 & 7 & 6.9 & 122 \\
\hline
\end{tabular}

* Excluding one uncleaved ovum.

Endometrium in the areas of the spirals was usually infiltrated by small numbers of leucocytes, predominantly polymorphonuclear neutrophils. These cells were sometimes scattered through the endometrium or concentrated around a few glands, but more often they were lying just under the endometrial epithelium. Since all uterine tissues examined were from ewes killed at oestrus or 3 days later, it is not known whether the degree of leucocytic infiltration varied during the oestrous cycle.

Leucocytic responses to intra-uterine devices have been reported in some animals of other species, e.g. rabbits (Carleton \& Phelps, 1933), rats (Kar, Kamboj, Goswami \& Chowdhury, 1965) and cows (Hawk, Conley, Brinsfield \& Righter, 1964), and the inflammatory response has been implicated in the impaired fertility of rats (Greenwald, 1965).

\section{Ovum fertilization following intra-uterine insemination}

Two ova from unmated experimental ewes were cleaving normally 2 days after transfer into oviducts of mated control ewes (Hawk, 1965). In an initial attempt to determine whether ova could be fertilized in the oviducts of ewes with a spiral in the uterus, semen was injected into the anterior uterine horns of five experimental and five control oestrous ewes in pairs. 
Three days later, each of seven ova recovered from control ewes was cleaving normally. Seven of eight ova recovered from experimental ewes were also cleaving normally (Table 3 ); three cleaving ova were recovered from oviducts on the side of the spiral and five ova, four of them cleaving, were recovered from oviducts contralateral to the spiral. Blastomeres ranged in number from four to twelve in control ewes and four to nine in experimental ewes; the most frequent number was eight in each group. These results indicated that both spermatozoa and ova could accomplish their roles in the process of fertilization in the oviducts of experimental ewes, providing that spermatozoa reached the site of fertilization.

The numbers of spermatozoa embedded in or attached to the zonae varied from about sixty-four to more than 180 for control ewes. The mean of 122 (Table 3 ) is the mean of approximate numbers only. In some cases the spermatozoa were too dense to obtain accurate counts, and many spermatozoa floated

TABLE 4

SPERM DISTRIBUTION IN THE REPRODUCTIVE TRACT AFTER INJEGTION OF SEMEN INTO ONE UTERINE HORN

\begin{tabular}{|c|c|c|c|c|c|c|}
\hline \multirow{2}{*}{$\begin{array}{l}\text { Eze group and } \\
\text { factor measured }\end{array}$} & \multicolumn{2}{|c|}{$\begin{array}{l}\text { Site of semen } \\
\text { injection }\end{array}$} & \multicolumn{2}{|c|}{$\begin{array}{l}\text { Contralateral to } \\
\text { semen injection }\end{array}$} & \multirow{2}{*}{$\begin{array}{c}\text { Uterine } \\
\text { body }\end{array}$} & \multirow{2}{*}{ Cervix } \\
\hline & Oviduct & $\begin{array}{c}\text { Uterine } \\
\text { horn }\end{array}$ & Oviduct & $\begin{array}{c}\text { Uterine } \\
\text { horn }\end{array}$ & & \\
\hline $\begin{array}{l}\text { Control }(5 \text { ewes) } \\
\text { No of spermatozoa } \\
\text { Intact spermatozoa }(\%)\end{array}$ & $95^{1.9}$ & $\begin{array}{r}631 \\
82\end{array}$ & $98^{3 \cdot 2}$ & $\begin{array}{r}708 \\
97\end{array}$ & $\begin{array}{l}76 \\
82\end{array}$ & $\begin{array}{r}1410 \\
96\end{array}$ \\
\hline $\begin{array}{l}\text { Experimental (5 ewes) } \\
\text { No. of spermatozoa* } \\
\text { Intact spermatozoa }(\%)\end{array}$ & 96 & $\begin{array}{r}436 \\
65\end{array}$ & $\begin{array}{c}0.2 \\
86\end{array}$ & $\begin{array}{c}2340 \dagger \\
19\end{array}$ & $\begin{array}{r}166 \\
52\end{array}$ & $\begin{array}{r}501 \\
79\end{array}$ \\
\hline
\end{tabular}

* Sperm numbers are in thousands; the mean number of spermatozoa injected into each ewe was 145 million, essentially all intact.

$\dagger$ These uterine horns contained the spiral.

free when the ova were flattened for sperm counting. The numbers of spermatozoa counted in ova from experimental ewes ranged from none to seventeen, the mean being significantly less than that for the control group $(P<0.01)$.

This difference in numbers of spermatozoa in the zonae suggested that intrauterine spirals might have influenced the patterns of sperm movement away from the injection sites. This possibility was tested in the next experiment.

\section{Sperm movement after intra-uterine insemination}

At $6 \mathrm{hr}$ after the injection of semen into the lumen of one uterine horn, spermatozoa were distributed throughout the reproductive tracts both of control and experimental ewes (Table 4). There was no conclusive evidence that spirals influenced sperm movement. The number of spermatozoa flushed from individual oviducts of experimental ewes varied from eighteen to 8750 on the side of semen injection and twelve to 2250 on the opposite side. In control ewes, the numbers varied from twenty-five to 34,300 on the side of semen injection 
and nineteen to 38,100 on the opposite side. Individual ewes tended to have either high or low numbers in both oviducts. The differences among the four means were not significant statistically, although sperm numbers tended to be smaller in oviducts of experimental ewes. Because of differences in experimental procedure, these results are not directly comparable with those of the previous experiment, in which sperm numbers in zonae differed between experimental and control ewes.

Experimental ewes had relatively high numbers of spermatozoa in the uterine horns opposite the side of semen injection, i.e. in the horn containing the spiral. However, only $19 \%$ of these spermatozoa were intact (Table 4 ). The remainder were broken at the juncture of the head and neck into completely separated heads and tails.

It was noted that spirals lying free within the uterine lumen when semen was injected had usually moved posteriorly when the ewes were killed, and often had partially entered the cervix. This was noticed even more frequently in the experiment on ovum fertilization after intra-uterine insemination. In contrast, spirals in ewes killed for study of ovum fertilization and sperm transport following natural mating had been lying free within the uterine lumen for months without being moved into the cervix. Thus, it may be suspected that exteriorization and handling of the uterus when semen was injected initiated uterine motility which did not ordinarily occur in experimental ewes, even after natural mating.

\section{Sperm breakage in the uterus}

Initial attempts were made to study sperm breakage after injection of about 50,000 spermatozoa in diluted semen into ligated uterine horns. However, very few if any spermatozoa could be recovered $5 \mathrm{hr}$ later. Larger numbers of spermatozoa, usually between 150 and 200 million, were subsequently injected so that spermatozoa could always be recovered from the uterine lumens. Uteri were flushed $5 \mathrm{hr}$ after semen injection, a time chosen to precede the acute leucocytic response to the semen.

The group of ewes available for this experiment was somewhat heterogeneous. Spirals had been inserted between 9 and 215 days before the oestrous period at which semen was injected into the uterus, and three of the eight experimental ewes had a spiral in each uterine horn.

In three control ewes, most of the injected spermatozoa were recovered, and $90.3 \%$ were intact (Table 5). Similarly, from the non-spiral uterine horns or segments in the eight experimental ewes, most of the injected spermatozoa were recovered and $79.4 \%$ were intact; from 'spiral' compartments in these ewes, a smaller percentage of spermatozoa was recovered, and only $23.1 \%$ were intact $(P<0.01)$. This was similar to the difference between spiral and nonspiral horns of experimental ewes in the previous experiment.

The local spiral effect was particularly noticeable in three ewes with a spiral in each uterine horn. Each horn was ligated into two segments, one containing the spiral. From the non-spiral segments of the three ewes, $86.5 \%$ of the recovered spermatozoa were intact; from the spiral segments, $7.8 \%$ were intact. 
The length of time that spirals had been in utero may have influenced the effect on spermatozoa. From three ewes with spirals in utero for 9 to 21 days, $47.0 \%$ of the spermatozoa recovered from spiral horns were intact; from five ewes with spirals in utero for 45 to 215 days, $8.8 \%$ were intact.

Uterine flushings always contained essentially equal numbers of separated heads and tails. The detached tails were sometimes bent or crinkled.

Any preferential phagocytosis of intact spermatozoa or selective recovery of broken spermatozoa could not have accounted for the high percentage of broken spermatozoa recovered from the spiral horns or segments. This point was especially evident in the three ewes with spirals in each horn. The number of spermatozoa injected averaged 210 million, essentially all intact. The number recovered averaged 179 million, and only $7.8 \%$ were intact.

The percentage of injected spermatozoa recovered from the spiral segments was lower than that recovered from non-spiral segments (Table 5). Considerable numbers of phagocytosed spermatozoa were seen in flushings from spiral

TABLE 5

EFFEGT OF INTRA-UTERINE PLASTIC SPIRALS ON SPERM INTEGRITY IN THE UTERINE LUMEN

\begin{tabular}{l|c|c|c|c}
\hline \multicolumn{1}{|c|}{ Ewe group } & $\begin{array}{c}\text { No. } \\
\text { of } \\
\text { ewes }\end{array}$ & $\begin{array}{c}\text { Mean No. of } \\
\text { spermatozoa } \\
\text { injected } \\
\text { (millions) }\end{array}$ & $\begin{array}{c}\text { Mean No. of } \\
\text { spermatozoa } \\
\text { recovered } \\
\text { (millions) }\end{array}$ & $\begin{array}{c}\text { Intact } \\
\text { spermatozoa } \\
(\%)\end{array}$ \\
\hline Control & 3 & 156 & 147 & $90 \cdot 3$ \\
\hline $\begin{array}{l}\text { Experimental } \\
\text { Spiral segments or horns } \\
\text { Non-spiral segments or horns }\end{array}$ & 8 & 184 & 106 & 23.1 \\
\hline
\end{tabular}

segments of the three ewes with spirals in place for 9 to 21 days; unobserved phagocytosis or even a highly efficient cytolytic mechanism could also have been involved in sperm disappearance.

Leucocytes were consistently present in greater numbers in flushings from spiral horns or segments than non-spiral horns or segments. This difference was undoubtedly due to the initial presence of leucocytes around the spirals. Whether the leucocytes were directly or indirectly responsible for the sperm breakage is not known.

Flushings from some uterine horns were moderately bloody, more often from spiral than non-spiral areas. Blood in the flushings was often associated with haemorrhagic endometrium around the base of the caruncles, suggesting that spirals may have affected vascular fragility. There was no apparent relationship between the bloodiness of flushings and the condition of the recovered spermatozoa.

\section{DISCUSSION}

There is no doubt that intra-uterine spirals inhibit ovum fertilization in sheep following natural mating. During this study and a previous one (Hawk, 1965), 
thirty ova were recovered from twenty-five ewes with one or two spirals in the uterus, and only one was cleaving; eighteen of nineteen ova from sixteen control ewes were cleaving.

Ovulation in experimental ewes occurred at the proper time in relation to the beginning of oestrus (Hawk, 1965), and ova from these ewes were fertilizable either in their own oviducts or in oviducts of other ewes. The paucity of spermatozoa flushed from oviducts and the low numbers of spermatozoa flushed from uterine horns of experimental ewes almost certainly means that spirals interfere with the normal movement of spermatozoa into the oviducts. The interference is more than mechanical because a total of ten ova were recovered from oviducts contralateral to the uterine horn containing the spiral and only one was fertilized.

Spirals promoted conditions in the uterus that resulted in breakage of spermatozoa, phagocytosis of spermatozoa, and perhaps in their unexplained disappearance. However, these things were observed for the most part after intra-uterine insemination and then primarily in the uterine horn containing the spiral. Therefore, it seems questionable whether these factors were major causes of inhibited ovum fertilization following natural mating. Rapid lysis of spermatozoa as they enter the uterus is a possibility, but it seems more likely that the absence of spermatozoa from the oviducts was due to interference by intra-uterine spirals with the physiological mechanisms normally involved in sperm transport.

Sperm breakage was noted in the two experimental ewes with the highest numbers of spermatozoa in the uterus following natural insemination, so it is conceivable that sperm breakage might be a major anti-fertility factor if sperm transport into the uterus occurred normally. The sperm breakage, possibly due to enzymatic activity, may have been related to the mild inflammatory conditions around the spiral.

Except for artificially inseminated cattle (Hawk et al., 1964), the sheep is the only species in which it is known that intra-uterine devices interfere with sperm transport and ovum fertilization. Spermatozoa have been found in the oviducts of humans and superovulated monkeys with a device in the uterine lumen (Malkani \& Sujan, 1964; Mastroianni \& Hongsonand, 1964) and ovum fertilization occurs in rodents. Other known effects of mechanical objects in the uterine lumen on the reproductive process include the following: inhibition of blastocyst implantation in rats (Doyle \& Margolis, 1964; Kar et al., 1965), which is apparently due to passage of blastocysts out of the uterus (Greenwald, 1965); inhibition of blastocyst implantation and detrimental effects on embryos in rabbits (Adams \& Eckstein, 1965; Marston \& Chang, 1964); inhibition of ovulation in Indian water buffaloes (Buch, Shukla \& Hawk, 1964); and hastened ovum transport in superovulated monkeys (Mastroianni \& Hongsonand, 1964).

\section{ACKNOWLEDGMENTS}

The author gratefully acknowledges the technical assistance of T. H. Brinsfield, H. H. Conley, B. Cox and F. Stormshak.

This study was supported in part by a reimbursable agreement with the 
National Institute of Child Health and Human Development, National Institutes of Health, Bethesda, Maryland.

\section{REFERENCES}

Adams, C. E. \& Eckstern, P. (1965) Effect of intra-uterine silk threads on location and survival of conceptuses in the rabbit. F. Reprod. Fert. 9, 351.

Buch, N. C., ShuKLA, K. P. \& HAWK, H. W. (1964) Interference with ovulation by intra-uterine plastic devices in Indian water buffaloes. Proc. Vth int. Cong. Anim. Reprod., Trento, 2, 242.

Carleton, H. M. \& Phelps, H. J. (1933) Birth control studies. III. Experimental observations on the Grafenberg ring contraceptive methods. 7. Obstet. Gynaec. Br. Emp. 40, 81.

DoyLe, L. L. \& MARgolss, A. J. (1964) Intra-uterine foreign body. I. Effect on reproductive processes in the rat. Fert. Steril. 15, 597.

GreENWALD, G. S. (1965) Interruption of pregnancy in the rat by a uterine suture. F. Reprod. Fert. 9, 9.

HAwK, H. W. (1965) Inhibition of ovum fertilization in the ewe by intra-uterine plastic spirals. $\mathcal{F}$. Reprod. Fert. 10, 267.

Hawk, H. W., Conley, H. H., Brinsfield, T. H. \& Righter, H. F. (1964) Contraceptive effect of plastic devices in cattle uteri. Proc. Ind int. Conf. Intra-Uterine Contraception, p. 189. Excerpta Medica Foundation, New York.

Kar, A. B., KamboJ, V. P., Goswami, A. \& Chowdhury, S. R. (1965) Effect of an intra-uterine contraceptive suture on the uterus and fertility of rats. 7. Reprod. Fert. 9, 317.

Malkani, P. K. \& Sujan, S. (1964) Sperm migration in the female reproductive tract in the presence of intrauterine devices. Am. 7. Obstet. Gynec. 88, 963.

Marston, J. H. \& Chang, M. C. (1964) Action of intra-uterine foreign bodies in the rat and rabbit. Proc. IInd int. Conf. Intra-Uterine Contraception, p. 242. Excerpta Medica Foundation, New York.

Mastroianni, L. \& Hongsonand, C. (1964) Mechanism of action of the intra-uterine contraceptive device in the primate. I. Tubal transport of ova and distribution of spermatozoa. Proc. IInd int. Conf. Intra-Uterine Contraception, p. 194. Excerpta Medica Foundation, New York. 